\title{
The Fallacy of Treating the Ad Baculum as a Fallacy
}

\section{Don S. Levi}

University of Oregon

\begin{abstract}
The ad baculum is not a fallacy in an argument, but is offered instead of an argument to put an end to further argument. This claim is the basis for criticizing Michael Wreen's "neo-traditionalism," which yields misreadings of supposed cases of the ad baculum because of its rejection of any consideration of what the person using the ad baculum, or someone who refers to that use as an "argument," is doing. The paper concludes with reflections on the values that should inform talk of a fallacy in an argument such as the one that Wreen is giving.
\end{abstract}

Résumé: L'argument ad baculum n'est pas un sophisme dans un argument, mais il est avancé au lieu d'un argument pour mettre fin à l'argumentation. Cet énoncé est le fondement d'une critique du "néotraditionalisme" (de Michael Wreen) qui ne tient pas compte de l'action de la personne qui emploie ou qui se réfère à un argument ad baculum, et qui pas conséquent suscite des mauvaises interprétations des soi-disants arguments ad baculum. Cet article se termine par quelques réflexions sur les valeurs qui devraient guider les discussions sur les sophismes, telles que celle de Wreen.

Keywords: ad baculum, fallacy, argument, premises, conclusion, thetorical tactic, speech act, dialogical exchange, context, audience, issue, context.

The ad baculum is not a fallacy. Many supposed examples are not cases of the ad baculum because no arguing is going on. Even when it is going on, the ad baculum is objectionable not because of some mistake in the argument or because some procedural rule for discussion has been violated, but because intimidation is used instead of argument to put an end to further discussion. These are some of the points I want to make in this essay.

However, my focus is on what happens when a logician is determined to turn the ad baculum into an argument. The logician I concentrate on is Michael Wreen, who has written many essays on the ad baculum. I begin by explaining how he reads the threat of a mugger as an argument the mugger is giving, and I try to show why his reading is a misreading. I also try to show that other readings he gives are misreadings. These misreadings are due, at least in part, to his determination to concentrate only on the logic of an ad baculum while ignoring rhetorical considerations. In what follows, I examine his reasons for doing so. A strength of his account is that he is concerned with considering the argument in its context. 
However, his understanding of what is involved in supplying the details of that context is limited, a point I also develop.

What is most intriguing about Wreen's analyses is how he knows what the premises and conclusion are of the argument that he thinks the adbaculizer is giving. After a critical examination of the epistemology of his reconstruction of rhetoric as an argument, I reflect on what is involved in identifying something as an argument. I conclude with some thoughts on what we are doing when we identify a fallacy in an argument.

\section{Wreen on the mugging as a non-fallacious ad baculum}

Wreen's work is of especial interest because, like the best philosophers, he does not shrink from acknowledging even the most paradoxical consequences of his self-styled "neo-traditionalism" (1994b) concerning what an argument is and how it is to be reconstructed and evaluated. An amusing illustration of how far he is prepared to go is provided by the classic Jack Benny skit, where a mugger holds a gun on Benny and says, "Your money or your life." Benny does not respond, and after a pause the mugger repeats his threat. "I'm thinking, I'm thinking," Benny tells him. The joke is that Benny is so reluctant to part with his money that the mugger's threat to kill him if he does not hand over his money is understood by Benny as an offer to choose between being killed or giving up his money.

Wreen doesn't seem to realize that it is a joke. He understands the mugger, as Benny does, namely, as inviting Benny to think about something. I say this because Wreen interprets the mugger as an appealing to Benny's self-interest. Wreen supposes that the mugger is giving an argument (presumably, because what he says is designed to get Benny to hand over his money), and that it should be formulated as the following sequence:

If you don't give me your money, I will shoot you.

My shooting you is a substantial disvalue to you.

So, you ought, from the standpoint of self-interest, to give me your money.

According to this reading, Benny is being invited to think about whether it really is in his best interests to give the mugger the money. Wreen's formulation of the conclusion seems awkward because he wants it to be the conclusion of a practical syllogism, i.e., because he wants to make clear that the objective of the conclusion is to get the victim to act.

Wreen thinks that the argument he constructs from the mugger's words should concern the fallacy theoretician for several reasons. One reason is that he thinks it is an example of the ad baculum. This seems so obvious to him that he sees no need to explain why it is, even though the mugger is not arguing with his victim and the threat is not designed to encourage his victim to do any arguing. 
Another reason why Wreen thinks that the mugging is of interest is that the argument is not fallacious, that it is a good inductive argument. It is not deductively valid because the conclusion may be false when the premises are true: Benny's interest in retaining what is his pockets might outweigh what he might lose by being shot. However, since the premises obviously provide support for the conclusion: it is a good inductive argument, although the strength of that support will depend on the circumstances.

Still another reason for Wreen's interest in the example is that he thinks that the mugger's argument is of a certain form: the premises state what will take place (or has taken place) if something is not done, and how its not being done is a substantial disvalue to the individual; the conclusion states what ought to be done by that individual (from the standpoint of that individual's self interest). Since arguments of this form can be good arguments, it is a mistake to say that the ad baculum is a fallacy, i.e., to say that an argument is a fallacy because it is ad baculum.

There are very puzzling consequences, which Wreen himself does not fail to point out, that follow from his claim to have determined what is essential to an argument's being ad baculum. Since the first premise need not be a threat (or anything intimidating or coercive), the ad baculum need not involve an appeal to force. So, surprisingly, a shouted warning to a pedestrian of an approaching car can be reconstructed as ad baculum, even though no one other than Wreen thinks so.The price on a store item also qualifies as an ad baculum because, as Wreen reconstructs the argument, the store is saying that if you don't pay the price on the item then you can't take it home with you, and not doing so is of disvalue to you. Also ad baculum, according to Wreen, is a contract you make with yourself to impose a sanction on yourself if you do not fulfill the terms of the contract, and so, too, is threatening your pet dog with a rolled up newspaper to get her to stop chewing the carpet (even if this approach to dog discipline seems ill advised).

Rather than be concerned about these bewildering consequences, I want to concentrate instead on his readings, and, in particular, his reading of the mugging. What is troubling about the latter is that it seems to credit the mugger with concern for his victim. We may imagine the mugger to say, "Don't think of resisting. You are going to be badly hurt or even killed if you resist." If this seems like an appeal to the victim's self-interest it is because the mugger's trying to get the victim to take his threat seriously is confused with his expressing a concern for her. Even a mugger who is apologetic about the stick-up-"I know you don't want to be shot. So, please don't make things worse for yourself by resisting. All I want is your money"-is threatening to shoot his victim if she does not comply; so, whether the mugger is brutal or kindly, it is still a mugging.

The key to understanding how Wreen arrived at his puzzling reading of the mugger as appealing to his victim's self-interest is that Wreen is concerned with what the mugger's conclusion is, and not with what the mugger is doing. What is 
the mugger's conclusion? If we answer this complex question we are making the mistake of conceding that the mugger is giving an argument. Among Wreen's (1989) requirements for properly reconstructing an argument is "paying close attention to the content of the particular proposition being argued for, especially if it isn't explicitly stated" (p. 135). I would have preferred him to talk about the position, not the proposition, being argued for. However, the real problem I have with Wreen's approach is how he could know what is being argued for (or what the mugger's conclusion is) when no arguing is going on.

The question of whether a conclusion is being argued for also arises with many of the other examples that Wreen discusses. A salesman tells Dagwood Bumstead that if he doesn't buy the window cleaner he is selling, he will beat Dagwood up (1995, p. 318). I am walking with Michael and fall into quicksand; instead of responding to my cries for help, he talks about how much he wants the diamond ring I am wearing (1988b, p. 434). A prison guard tells someone on death row that he can engineer an escape, but that it will take $\$ 150,000(1989$, p. 134$)$. A secretary tells her boss that he will give her a raise because he wouldn't want the wife to find out about his affair $(1989, \mathrm{pp} .135-6)$. The puzzling thing about these examples is that each of these people does not seem to be concluding anything, let alone giving an argument.

Consider, for example, the last example. We might suppose, in order to make it a plausible case of ad baculum, that the boss and secretary are engaged in an argument over her pay when she tries to blackmail him into giving her a raise. However, her blackmailing him should not be confused with her giving an argument. She says she should be given a raise, and he says that she is being paid the going rate for someone with her duties and experience. Rather than question this claim of his, she resorts to blackmail. When she does so, she no longer talks about what she should be paid, but about what she will be paid. She is employing a tactic (and it may be called an "ad baculum tactic"), but it is not a fallacy, because that suggests that she has made a mistake in arguing. Rather than address the issue he is raising about whether she is being paid adequately, her tactic is designed to make further argument irrelevant and unnecessary. Moreover, if arguing can be imagined to be going on in any of the other cases, then if, as in the Dagwood example, the tactic really is ad baculum, it, too, is being used to put an end to the argument.

So, none of these examples is a fallacy in argument because no argument is being given even though it is alleged that the ad baculum is used. The speaker, by soliciting a bribe, relying on extortion or using the threat of force to rob his victim, is using an objectionable tactic. However, in none of these cases is any argument given.

\section{The ad baculum as a tactic to avoid or put an end to argument}

As I've suggested above, the ad baculum is really a rhetorical tactic used to put an end to further argument. Before considering how Wreen is going to respond, let 
me try to explain and clarify my reclassification of the ad baculum as a rhetorical tactic that is offered to put an end to any further argument. That it is offered to end the argument is important to the characterization because people often raise their voices or interrupt or even say threatening things because they are impatient and excited, and not, necessarily, to get their way in the argument. Even when such bullying is done for this purpose, there is no appeal to something coercive when the arguer raises his voice or interrupts. When the appeal is being made that seems characteristic of ad baculum rhetoric, the person who is making the appeal is doing so rather than addressing the issues raised by his audience. That is to say, he is opting out of the argument.

Informal logicians who theorize about the ad baculum in terms of what the person using it is doing in the context of a dialogical exchange seem to be saying the same thing about the ad baculum that I have been saying about it. However, there are significant differences between us.

Consider Walton (1989), for example. He says that the ad baculum is "used as a tactic not only to divert an argument, but even to try to prevent the argument from getting started or to prevent the procedure of dialogue from getting underway" (p. 99). However, if I am right that the ad baculum should not be classified as a fallacy, then there would be no reason for Walton to diagnose it as a violation of dialogue or discussion procedures. Not only is there a problem with the suggestion that such procedures actually exist, there also is a problem with the suggestion that it is the violation of some procedure, rather than the bullying or coercion, that is objectionable. When what we are talking about is the rhetorical tactic of bullying or intimidating the audience into stopping from continuing to argue, it seems to put the emphasis in the wrong place to complain about how the bullying or intimidation violates a discussion procedure.

Rather than talk, as Walton does, of what the ad baculum does to an "argument," Eemeren and Grootendorst (1992) talk of what it does to the advancement of a "standpoint." As they see it, the ad baculum violates the "right of free speech", the prohibition of which is formulated as their rule one for "critical discussion":

Parties must not prevent each other from advancing standpoints or casting doubt on standpoints. (p. 108)

The adbaculizer, by using a threat or intimidation to prevent or put an end to further discussion, seems to be violating this rule.

However, there are several problems with their analysis. One is that it makes the unwarranted assumption that people are clear enough about what they are doing when they argue to have standpoints they are advancing or questioning. Another is that it encourages us to treat all sorts of things that people might be doing, including expressing anxiety, interest or concern, as the advancement of a standpoint. Still another is the problem that also troubles Walton's analysis, the problem of why it is more critical for the ad baculum to violate a rule of discussion than for it to involve bullying or intimidation (or worse). 
Despite the apparent similarities between my approach and the others that I have been discussing, there is an underlying difference between us. I have been arguing that the ad baculum is not an argument. If I am right, then there is no reason for trying, as Eemeren and Grootendorst do, to find a model comprehensive enough to explain what makes any fallacy, including the ad baculum, a fallacy. If I am right, then much of the momentum is lost for trying to find, as Walton does, a characterization of it that distinguishes between fallacious and non-fallacious cases.

Before concluding this section, I want to say something about the project of characterizing the ad baculum so that it will be clear whether or not something is a case of it. Wreen assumes that there must be something that an ad baculum essentially is in order for it to be possible to correctly apply the label, whereas I reject such an essentialistic approach. I have contented myself with a characterization that seems to fit representative cases of the ad baculum, but I think it is wrong to suppose that there is something that makes these cases what they are (and wrong, too, to suppose, as Wreen does, that that something is an argument form, albeit one with instances that are not fallacious). After it has become clear that the arguer is relying on bullying or intimidation as a sustitute for what arguing should have accomplished, then the diagnostic label of "ad baculum" may be utilized. But the label cannot be used, as many informal logicians seem to suppose, to enable us to determine that some mistake has been made.

To see what I have in mind, consider labor and management negotiations over a new contract. The threat of a strike (or lockout) is part of those negotiations, something that both sides may have to consider when they consider the advantages and disadvantages of different contract terms. The threat is not offered as a substitute for argument; rather, it is part of the negotiations. So, the fact that the threat has been made is not sufficient for it to be characterized as ad baculum. This is because, as I see it, referring to something as ad baculum, if there is any point in doing so, should be understood as accompanying a critique of the rhetoric of the person using it, and not as the basis for that critique.

\section{Wreen on the irrelevance of what the speaker is doing}

The points I have been making about the ad baculum would be rejected by Wreen. Not only would he want to insist that ad baculum rhetoric is an argument, he would also take exception to the approach I have been taking in my criticism of his reconstruction of the mugger's words. Wreen thinks that what the mugger is doing in saying what he does is irrelevant to the content of his argument, and the same point applies to what the speaker is doing in the other examples he discusses:

whether the speech act performed is threatening or warning ... or anything else for that matter, is of no logical moment. ... What matters is whether my premises are true and how they support my conclusion. The speech act performed is, as far as I can see, logically irrelevant. (1988b, p. 434) 
Wreen's position is that since the argument, as he reconstructs it, involves no reference to anything threatening or even intimidating, how the argument is understood or evaluated is unrelated to such matters.

Consequently, Wreen would object to my wondering what the mugger could be doing when he is understood to be concluding, "You ought, from the standpoint of self-interest, to give me your money." He would object to it because talking of what the mugger is doing (appealing to self-interest or threatening) refers to a "rhetorical" consideration, which does not "make any difference to argument content, structure or evaluation" (1995, p. 334).

However, if rhetorical considerations are ruled out as irrelevant, how can Wreen know that an argument is being given? He obviously thinks that the mugger is arguing for some conclusion, even though the mugger is not performing the speech act of arguing; he also thinks that the secretary is giving an argument when she tries to blackmail her boss, even though she is trying to put an end to any further argument by doing so. But, if his reference to "arguing" is wrong or misleading, and he does not think it matters anyway whether or not the mugger or secretary is arguing, then the question arises as to why he is assuming that an argument has been given.

That there is a problem with his assumption that rhetorical considerations are not relevant logically is obscured by Wreen's way of proceeding. He formulates the premises and conclusion that he says constitute the argument, and then tells us that the only relevant logical considerations are whether the premises are true or whether they provide adequate support for the conclusion. However, he seems to neglect the fact that there is a problem understanding what the "propositions" of this argument are supposed to say or mean, how they can be understood as premises or as the conclusion.

Consider, for example, the first premise of the mugger's argument, as Wreen would reconstruct it: "If you don't give me the money, I will shoot you." I understood this to be a threat, but Wreen thinks that it need not be understood that way. The fact that because it is a premise (and a proposition) it is supposed to admit of truth or falsity suggests that we think of it as a prediction, but that won't work because the mugger is not making a prediction. Moreover, predicting is a speech act, and Wreen does not want that. The reference to a "proposition" suggests that we understand the mugger to be making a statement or claim, but that is not what he is doing. Nor is he making his victim a proposition, at least not in the sense of a business proposition. I conclude that Wreen thinks there is something distinct from the threat or prediction, something that is true or false, but which we are not to imagine as being said.

If so, then there is an unwarranted assumption, in Wreen's approach, namely, that the content of what the mugger (or any of Wreen's other supposed adbaculizers) is saying, the content of the propositions that can be attributed to him, can be considered independently of what he is doing in saying what he does. Wreen 
wants to insist that, "If you don't move, you'll be crushed by a falling rock," is the same proposition whether the speaker is warning someone about a dangerous boulder or threatening her by indicating that he will dislodge it unless she does what he wants. He insists on it despite the fact that the warning and threat, when stated in different words - "Watch out for the falling rocks!" and "I'll make these rocks fall on you if you don't do what I want."-could hardly be confused with one another.

His insistence seems based on mistakenly assuming that the content of the warning or threat is really a proposition that we can understand without having to consider who is saying it or when it is being said. The assumption is mistaken because if we are not to consider the proposition as something someone is actually making (or saying), then Wreen himself must be the one who is giving it a content, and it hard to see how could do that unless it had a content already.

Wreen prides himself on not neglecting the context of an argument, so we need to explain how he can emphasize its importance and yet not take pains to make clear that the context in question is that of actual discourse. The next section is devoted to trying to explain it.

\section{The importance of considering an argument in its context}

Wreen (1989) himself reminds us about the importance of "considering the argument in its context" or of "imputing a plausible one" for the argument if one is not obvious (p. 135). However, what he means by 'context' has more to do with supplying details to make the "argument" plausible, than it does with telling us enough to help us to understand what was said. To see why I say this, consider Wreen's most extended treatment of an example, which is to be found in his first published essay on the ad baculum (1987).

The example he is discussing is one of Copi's (1987):

Of course there is a Santa Claus. But he doesn't bring any presents to children who don't believe in him (p. 110).

Since Copi refers to it as a fallacy, Wreen's efforts are devoted to making sense of it as an argument. He imagines that a child, Virginia, has been told by an older sibling or friend that Santa Claus doesn't exist, and that Virginia has come to her mother for help. To make the mother's response into an argument, Wreen has her arguing that the Santa sceptics have not been receiving presents and that Santa has punished them for their refusal to believe in him by giving them no presents. Thus, by giving an argument discrediting the claims of the sceptics, the mother has reaffirmed Santa Claus's existence.

Wreen's reconstruction is interesting because all his efforts have gone into trying to make something out of the mother's answer that he could consider to be an argument, and he seems to have neglected any consideration of how that argument could actually be given by a mother to a daughter who is young enough to 


\section{The Faliacy of Treating the Ad Baculum as a Fallacy}

still believe in Santa. Imagine, for example, how the child may react when she is told that kids who do not believe in Santa have not been receiving any Christmas presents.

"Mommy, I've seen their presents."

"You've seen what they have told you are their presents. They didn't get any presents."

There are kids who don't receive any presents because they are runaways or victims of extreme parental neglect. However it is hard to imagine how a sane parent could seriously be suggesting that these children are being punished by Santa for not believing in him. There also are non-Christian children whose families don't give Christmas presents. However, the fact that they get no presents provides no basis for a threat to Virginia because the other children do not expect gifts and so it makes no sense to suggest that they are being punished by not being given what they would not expect to receive.

Wreen's reading is not designed, as you might think, as a reductio ad absurdum of Copi's suggestion that the mother is giving an argument, albeit a fallacious one. It is not designed that way because Wreen himself seems unwilling to give the mother's words the kind of reading that would be more likely to be given to them if they did not have to be read as an argument that is somehow being given to a very young child. As I read her reply in the original Copi example, the mother is uncomfortable with Virginia's question. Instead of replying directly, she gives a wise-ass response. If Virginia sees the humor in it, then she is probably too old to believe in Santa Claus anyway; if not, the mother's response may have the desired effect of getting Virginia to stop asking the question.

\section{The problem of identifying the premises and conclusion}

Now that I have tried to show how Wreen goes wrong when he mistakenly reads something as an argument, let me explain, what must seem mysterious, how Wreen can determine what the premises and conclusion of an argument are. He mistakenly assumes that there is something an ad baculum argument is essentially, which to him means that ad baculum arguments must all have something in common. To find what that essential feature is he studies an undoubted case of ad baculum rhetoric and tries to determine what it seems to have in common with other ad baculum cases.

To find that undoubted case he looks to Copi (1990), who talks about the threats of a lobbyist as an example of the ad baculum.

The lobbyist uses the ad baculum when he reminds a representative that he (the lobbyist) can influence so many thousands of voters in the representative's constituency, or so many potential contributors to campaign funds. Logically these considerations have nothing to do with the merit of the legislation the lobbyist is attempting to influence. But they may be, unfortunately, very persuasive. (pp. 91-92) 
As Copi imagines it, rather than address the issue of whether the legislation is good or bad, the lobbyist talks instead of the risks that the legislator would be taking by voting contrary to the way those the lobbyist represents wants her to vote.

However, Wreen tells us, Copi seems to have confused an argument over the merits of the legislation with an argument over how the legislator should vote. When Wreen makes this criticism of Copi, he does so in terms of the argument that is being given to the legislator. According to Wreen (1987), Copi's mistake is that he has failed to see that "the conclusion (the lobbyist is arguing for) is not that the bill (in question) is a good one, but that the politician ought, from the point of view of self interest, to support it" (p. 37). When what Wreen thinks is the right conclusion is properly identified, the one that he thinks makes a prudential appeal, the lobbyist's argument is not fallacious.

The problem with this criticism of Copi is that it depends on the assumption that the lobbyist is giving an argument. Although Wreen thinks that what speech act the lobbyist is performing is irrelevant to whether the argument is fallacious, he does concede that "in many cases, knowing what people are up to . . . can certainly be helpful in reconstructing an argument" (1995, p. 317). However, he nowhere acknowledges that there might be a problem in determining that an argument has been given, something I think is the real issue raised by his approach to the ad baculum.

To see why this is the issue, let us look at the lobbyist example more closely. That there is a problem finding an argument here is most evident if we understand the lobbyist to be threatening the politician when he "reminds" her that she will lose votes and campaign contributions. Imagine one of her advisors to question her about her decision to vote the way the lobbyist wants her to vote. "Did he have any argument for why you should do this?" "No," she answers. "But he did frighten me when he talked about the votes and contributions we would lose. I don't know whether we can afford to risk these losses." She and her advisor can argue about whether she should be worried about it; however, the lobbyist has not given any argument that should worry her. He has threatened her with the loss of votes and funds, but he has not said anything about why she has to have those votes or those contributions.

Let us do what Wreen suggests, let us take the threat out of it. To do that we have only to imagine that one of the legislator's advisors is discussing with her the risks of voting against capital punishment. He points out that a substantial number of her constituents are in favor of it, and that for her to vote against it will lose her a lot of votes and campaign contributions. Here the issue being raised by the advisor seems clear: can the legislator take the public position that she wants to take and afford the risks of doing so? The advisor takes the position that she cannot do so; however, he is not threatening her when he does so. 
Wreen wants to say at least two things about this example. One is that no threat is being made. The other is that the advice has what he thinks of as the ad baculum argument form, where the premises talk about the consequences of not doing something and the conclusion about what one ought not to do from the standpoint of self-interest.

However, his reading of the example depends on understanding the advisor to be giving an argument. For Wreen to be right about that, it is not enough that the advisor be insisting that the legislator's position is too risky; he must give an argument to that effect. This is the point that Wreen seems to miss. To insist that she cannot afford the costs of voting a certain way is merely to take a position on this issue but it is not to give an argument for that position. The advisor needs to say something about the voters and contributors who will be affected, and he needs to talk about the possibility of other support that may come their way because of her vote that will compensate for what she may lose by it.The advisor might want to argue that they do not have the resources to take the fight to the public, or that the legistator's supporters are too divided on the matter to be counted on to campaign effectively for votes or funds. If so, he may be said to have given an argument for her not voting against capital punishment, whereas all he seems to be doing on Wreen's reconstruction is taking a position without arguing for it.

\section{What an argument is}

It is at this point that the problem with Wreen's approach becomes apparent. According to his conception of an argument, the argument just is what he reconstructs as a sequence of premises-and-conclusion. The problem with his approach is with its operating assumption that what is reconstructed can be understood as an argument without having to imagine its premises and conclusion as actually being maintained in response to certain question and concerns.

A related problem in Wreen's thinking is that he sees no need to ask what he and we are doing by referring, for example, to what the politician's advisor says as an 'argument'. To see why this is a problem consider that when we ask whether the advisor has given an argument, we do so because we think something is at issue. Perhaps, we want the legislator to vote her conscience, but we are concerned, as she is, with whether she will be undermining her power base. We ask, "What is the argument for taking the risk of alienating these voters and contributors?" Or "What is the argument for our not being able to afford this risk?" The question reflects our concerns: "Will that many voters or contributors be influenced by this one issue?" "Will other sources for votes and funds become available, perhaps from those who will be impressed by her voting her conscience?" So, by not taking into account such rhetorical matters as what is at issue in the argument, Wreen fails to appreciate how references to something as an "argument" reflect what the person making that references is doing. 
This failure is evident in the case of the mugging example. What is the argument for the victim handing over her money? What reason did she have for giving her purse to a perfect stranger? These are the questions that Wreen seems to be encouraging us to ask. However, by asking either of them we would be suggesting that there is some problem with what she did. If we did not know she had been mugged, then her behavior in giving money to a perfect stranger will seem questionable. But, if we persist in asking for her reasons for handing over the money after we know that she had been mugged, then our doing so is puzzling, if not insulting, in its suggestion that there is something she needs to justify.

Wreen characterizes an argument as "simply offering a reason, or reasons, for a conclusion" (1988a, p. 91). This reference to a conclusion is best understood as the conclusion to something like a practical syllogism. That is to say, if the victim hands over the money because of the mugger's words (and actions), then what the mugger said and did gave her a "reason" for doing so, and so her decision to hand over the money can be considered as the conclusion of an argument whose premises state the consequences of her not doing so and what value those consequences have for her.

What Wreen is calling a "reason" is something that explains the victim's action without implying that her action is in need of justification. So, the question Wreen is asking when he wonders about her reason for acting is a question he asks as a philosopher or philosophical psychologist, a question he thinks he can ask without having to imagine when or whether someone would actually have the question.

However, it is not clear whether he really has a question about her behavior. Since Wreen knows that she was mugged, if he has a question about it, that question must be about why she gave the mugger the money when he threatened her with the gun. But, it is not easy to imagine what he could be asking. Some possibilities suggest themselves: What reason did she have for not thinking that the mugger was bluffing? What reason did she have for giving the mugger all of her money, rather than only some of it? However, the mugger's threat, which Wreen turns into an "argument," does not speak to either of these questions. Why didn't she do something foolish or risky like ignoring the mugger or trying to disarm him? From the little we know about the example, the mugger does not seem to have addressed this issue, but then I do not see why she needs a reason for not behaving suicidally if she is not suicidal. Without more information than we have been given about the mugging, it is hard to imagine someone to responsibly and seriously have a question about the victim's behavior.

Another way of stating the problem is to ask what the victim is supposed to have done which the "reason" rationalizes or explains. It is wrong to say that she just gave the mugger the money. What then did she do? The answer depends on what the issue is that we think is raised by her behavior, and we have no idea what that issue is. If we did know what the question is about her behavior, we can describe her, for example, as complying with what seems to have been a very 
feeble attempt at a mugging or as not putting up the resistance that the situation seemed to call for. However, as I read him, Wreen thinks that he has said enough about what she did for the mugger's threat to have been the reason for her doing it, and I am suggesting that he is wrong to think so, wrong to think that we know enough to know what she did that the reason is supposed to rationalize.

To sum up: when someone asks what the argument is, the question assumes that something is at issue which the argument is supposed to address. If Wreen thinks otherwise, it is because he assumes that the question can be asked and answered without there being any need to consider whether anything is at issue. It is this assumption which I have questioned in this section.

\section{Conclusion: what we are doing in referring to something as a "fallacy"}

Because of this and earlier references to a questionable assumption or other mistake in Wreen's thinking, I want to conclude this paper by discussing what we are doing when we refer to something as a "fallacy." As should be obvious from this paper, I think that although he is right to question whether intimidation or bullying or threatening is fallacious, he is right for the wrong reasons. His reason for thinking that it is not fallacious is that the argument when reconstructed properly is not fallacious. Not only do I think that it is a mistake for him to treat ad baculum rhetoric as an argument, but I also thinks that he goes wrong by not asking himself what we are doing when we refer to something as fallacious.

To see why this question is important, consider the following humorous misuse of the accusation of "fallacy."

Polly Espy: And stop shouting. I think shouting must be a fallacy too (Shulman, 1945, p. 61).

Dobie Gillis has been giving Polly lessons on the fallacies because, although he found her attractive, he did not think that she came up to his intellectual standards. When he decides that she has caught on to his lessons, and he tries to turn the relationship into a romantic one, he is thwarted when she uses what he has taught her to find fallacies in his romantic advances. He starts yelling when he discovers that his roommate, Petey Bellows, has broken his agreement with Dobie to give up any claim Petey might have on her. Polly's rejoinder is funny: even if shouting is not a fallacy, it certainly isn't going to do Dobie any good to point this out to her.

Mind you, Polly is right to complain about Dobie's shouting at her, as she would be right to complain about his interrupting or patronizing or failing to listen to her. Walton, Eemeren and Grootendorst, following Hamblin (1970), want to conceptualize these complaints by talking about the goals of dialogue and how these aims are thwarted by, for example, adbaculizing tactics. I sympathize with Wreen's (1994a) scepticism about whether rhetoric always is dialogical or always has goals, or whether these goals can be as limited as the dialogists assume. Where 
he goes wrong is in supposing that adbaculizing tactics may be treated as arguments, a mistake he makes because of his separation of logic from rhetoric. Shouting is not a fallacy, but it is rude and inconsiderate; intimidating tactics often succeed in getting people to do what you want them to do, but they still are tactics that should be condemned, even though Polly chose the wrong word-'fallacy'-to do so.

What are we doing when we talk, as I just did, about how someone has gone wrong (or has committed a fallacy)? When the focus is on sitting in judgement over what we take to be the argument that is given, then an unfavorable verdict seems patronizing or condescending. This emphasis on finding fault is not itself fallacious, but, like Dobie's shouting, it certainly is annoying and unhelpful, especially when it is not accompanied by any real interest in the issues that the argument addresses.

The emphasis on finding fault is due to a mistaken conception of argumentation as a potential mine-field the dangers of which those who teach or write about fallacies can help their students or clients avoid. This conception fails to acknowledge the value of argumentation in helping us to clarify what, if anything, we have to say that addresses our opposition. Often, we become clearer about what is at issue, or what, if anything, we have to say that addresses that issue, only after we engage in argumentation and because of it.

With this positive conception of argumentation in mind, the concept of a fallacy may be seen in a different delight. While it is true that sometimes reasoning or thinking is said to be fallacious in order to stigmatize it, there is another use of the term 'fallacy,' namely as a diagnostic tool that may help us to understand how the arguer is thinking. Rather than encourage us to sit in judgement over the argument, an analysis of an argument should be a means for helping the different sides of the dispute better to understand one another and perhaps find a way to resolve their conflict.

To illustrate what I have in mind, consider my references to a fallacy (or mistake) in Wreen's thinking. By telling him, for example, that the fallacy in his argument is that he thinks what is said can be separated from who said it, when and why it was said, and what the person was doing in saying it, I am pointing to what I think is at issue in his thinking. However, he does not seem to think that it is important to determine what is at issue before determining whether an argument has been given or before reconstructing that argument. That he does not think it is important is, I believe, the fallacy in his thinking.

Rather than end with this apparent condemnation of his work, let me emphasize that when I identify the fallacy in his thinking I am hopeful that my criticism will prompt him to respond critically; I realize that I need that response. This is because my position on the ad baculum and related subjects is constituted by its being a reaction to the views, among others, of neo-traditionalists like Wreen.Not only is my having something to say dependent on what Wreen and (others) have 
had to say, but my understanding of what I am saying is dependent on how well it anticipates Wreen's objections to my attack on his thinking. So, I need his critical reaction to my saying that there is a fallacy in his thinking, and that reaction will, hopefully, help me to acquire a better understanding of my own position.

\section{References}

Brinton, Alan. 1992. "The Ad Baculum Re-Clothed." Informal Logic 14, pp. 85-92.

Copi, Irving. 1987. Introduction to Logic, 7th edition. New York: MacMillan.

Deigh, John. 1995. Review of Douglas Walton, The Place of Emotion in Argument. Informal Logic 17, pp. 113-121.

Eemeren, Frans H. van and Grootendorst, Rob. 1992. Argumentation, Communication and Fallacies. Hillsdale, NJ: Lawrence Erlbaum Associates.

Hamblin, C.L. 1970. Fallacies. London: Methuen \& Company.

Jason, Gary. 1987. "On Argumentum ad Baculum," Philosophia 17, 491-99.

Shulman, Max. 1951. The Many Loves of Dobie Gillis. Garden City, NY: Doubleday and Company.

Walton, Douglas. 1989. Informal Logic. Cambridge: Cambridge University Press.

Walton, Douglas. 1992. The Place of Emotion in Argument. University Park, PA: Pennsylvania State University Press.

Woods, John. 1995. "Appeal to Force," in Hans Hansen and Robert Pinto, editors, Fallacies. University Park, PA: Pennsylvania University Press, pp. 240-50.

Walton, Douglas. 1987. "Ad baculum, Self-interest, and Pascal's wager," In Argumentation: Across the Lines of Discipline, Frans van Eemeren, Rob Grootendorst, Anthony Blair and Charles Willard, editors. Dordrecht: Foris Publications, pp. 343-9.

Wreen, Michael. 1987. "Yes, Virginia, There is a Santa Claus." Informal Logic 9, pp. 319.

Wreen, Michael. 1988a. "Admit No Force But Argument." Informal Logic 10, pp. 89-96. Wreen, Michael. 1988b. "May the Force Be With You." Argumentation 2, pp. 425-40. Wreen, Michael. 1989. "A Bolt of Fear." Philosophy and Rhetoric 22, pp. 131-40.

Wreen, Michael. 1994a. "Look, Ma! No Frans!" Pragmatics and Cognition 2, pp. 285306.

Wreen, Michael. 1994b. "What is a Fallacy?" In New Essays in Informal Logic, Ralph Johnson and Anthony Blair, editors. Windsor: Informal Logic.

Wreen, Michael. 1995. "Knockdown Arguments." Informal Logic 17, pp. 316-36.

Don S. Levi, Department of Philosophy 1295 University of Oregon, Eugene OR 97403-1295 U.S.A. dslevi@oregon.uoregon.edu 